\title{
PENGARUH BAHAN DAN TINGKAT PENGENCER SEMEN MENTOG YANG BERBEDA TERHADAP MOTILITAS PADA SUHU KAMAR
}

\author{
(The Influence Of Different Materials And Levels Diluted of Mentog Semen to Motility \\ In Room Temperature)
}

\section{Fitriani dan Sugiarti}

Fakultas Pertanian Universitas Islam Kalimantan Muhammad Arsyad Al Banjari

Jln.Adyaksa No.2 Kayutangi Banjarmasin

email:ipit.peternakan@gmail.com

Article Submitted : 17-07-2019

Article Accepted : 06-10-2019

\begin{abstract}
This research examined the effect motility quality of Muscovy semen. The quality were used to room temperature levels of semen diluter. Fress Muscovy semen diluted in 1. Ringer lactate 2. otsu RL dan 3. Sodium chloride and levels 5,10,15X and 0 (control). The result showed that the treatments not significantly affected motility of semen, the highest Muscovy semen in the ringer lactate diluted 5 and $10 \mathrm{X}(50,00 \pm 6,67) ;(45,55 \pm 6,93)$. The result of the study indicated not significantly affect motility Muscovy semen of determine and diluted.
\end{abstract}

Keyword: Motility, Muscovy, diluted.

\section{PENDAHULUAN}

Pebandingan jumlah pjantan dan betina dalam suatu peternakan unggas yang menghasilkan final stock berpengaruh pada fertlitas telur dan jumlah biaya yang dikeluarkan. Adanya bioteknogi menghasilkan inovasi permuliaan ternak dan reproduksi ternak, dengan teknik IB memerlukan ketersediaan semen yang berkualitas. Namun semen diluar tubuh bahan rapuh maka perlu media hidupnya dalam mempertahankan semen mentog. Kendalanya semen segar kerentanan semen diluar tubuh dimana bahannya rapuh akhirnya rentan/motilitas menurun, motilitas semen merupakan ciri utama dalam penilaian semen. Salah satu upaya yang dapat dilakukan digunakan semen segar yang diencerkan dengan bahan pengencer, mampu mempertahankan hidup sel semen yang tidak bersipat non toksin (tidak beracun) bagi semen mentog dapat memenuhi kebutuhan semen dan murah. Pengencer yang berlebih tidak dianjurkan dan waktu tempat penyimpanan (Toelihere, 1993).

\section{METODE PENELITIAN}

Penelitian dilaksanakan di Laboratorium lapang di Sekumpul Martapura dan uji motilitas dilaksanakan di dinas peternakan kabupaten banjar martapura untuk mengetahui kualitas semen mentog. Mentog yang digunakan dalam penelitian ini adalah 4 ekor ternak jantan yang sudah diadaptasi sekitar empat bulan dari dilatih penampungan semen yang berumur sekitar 8 - 1,5 tahun dengan berat badan $3-3,5 \mathrm{~kg}$. Penampungan semen entog dilakukan pagi hari antara jam $07.00-09.00$ dengan frekuensi penampungan $2 \mathrm{x} /$ minggu,

Kandang individu yang terbuat dari kawat dengan ukuran $60 \times 60 \times 80 \mathrm{~cm}$. Diadaptasikan dengan lingkungan selama empat sampai enam minggu, pakan yang diberikan yaitu campuran dengan dedak dan kosentrat tepung itik petelur (144) Pokphand 
yang terdiri: kadar air max $12.0 \%$, protein $\max 37.0$ - 39.0\%, lemak min $2.0 \%$, serat $\max 6.0 \%$, abu $\max 35.0 \%$, calsium min $12.0 \%$ dan phosphor min $1.20 \%$, dengan perbandingan $(4: 1)+$ vitamin untuk itik petelur dicampur sedikit air diaduk sampai rata dan diberikan setiap pagi dan siang hari.

Metode penelitian yang digunakan metode eksperimental dengan Split Plot pola petak terbagi. Faktor pertama sebagai Petak Utama adalah bahan pengencer dan faktor kedua tingkat pengencer sebagai Anak Petak

\section{HASIL DAN PEMBAHASAN}

\section{Hasil pemeriksaan semen segar setelah penampungan}

Rataan volume semen entog perejakulasi yang diperoleh selama penelitian sebesar $(2.17 \pm 0.29) \mathrm{ml}$. Hasil penelitian ini menunjukkan bahwa volume semen yang dihasilkan banyak disebabkan semen yang didapat lebih encer. Diduga dihasilkan saat ejakulasi semen yang ditampung bercampur dengan sekresi lipatan - lipatan limpa dan pada suhu $4^{\circ} \mathrm{C}$. tiga kelompok (3 kandang mentog sebagai ulangan) yang diambil semennya.

Apabila hasil yang diperoleh melalui analisis ragam menunjukkan adanya pengaruh perbedaan yang nyata antar perlakuan $(0,05<\mathrm{P}<0,01)$, maka diuji lebih lanjut uji BNT. Beda Nyata Terkecil bertujuan untuk menentukan perlakuan perlakuan mana yang berbeda dengan yang lain (Stell dan Torrie, 1990).

badan - badan vaskuler di dalam cloaca sehingga encer. Ini sesuai dengan penyataan Hafez (2000) semen dibagi menjadi dua bagian padat disebut spermatozoa yang dihasilkan oleh testes dan bagian yang cair disebut seminal plasma (cairan semen) yang dihasilkan oleh kelenjar asesoris jantan 9 bulbo urethralis, prostata, vesicular seminalis, sekresi tersebut berfungsi sebagai buffer dan medium bagi spermatozoa agar daya hidupnya dapat dipertahankan secara normal setelah ejakulasi.

Tabel 1. Hasil Evaluasi Semen Mentog

\begin{tabular}{lc}
\hline Makroskopis & Rataan \pm SD \\
\hline a. Volume (ml) & $2.17 \pm 0.29$ \\
b. Warna & Putih s/d Putih keruh \\
c. Bau & Khas \\
d. Konsistensi & Encer s/d kental \\
e. $\mathrm{pH}$ & $7.16 \pm 0.288$ \\
\hline Mikroskopis & Rataan $\pm \mathrm{SD}$ \\
\hline a. Abnormalitas & 10.561 .17 \\
b. Motilitas massa & $++\mathrm{s} / \mathrm{d}+++$ \\
c. Motilitas individu (\%) & $70.00 \pm 5.00$ \\
d. Spermatozoa hidup (\%) & $70.00 \pm 5.00$ \\
\hline
\end{tabular}

Warna semen yang diperoleh selama penelitian adalah putih sampai putih keruh. Partodihardjo (1992) menyatakan bahwa warna semen unggas yang normal adalah putih susu, sedangkan derajat kekeruhannya tergantung pada konsentrasi semen yang ada, semakin keruh maka kosentrasinya semakin tinggi dan sebaliknya bila warna semen 
bening menunjukkan konsentrasi yang rendah. Pada perlakuan ini, semen yang berwarna putih keruh menunjukkan bahwa semen tersebut memiliki tingkat konsentrasi yang lebih tinggi dari pada semen yang berwarna putih.

Bau semen segar entog pada saat penelitian didapatkan bahwa bau khas ternak. Bau tersebut menunjukkan semen tersebut dalam keadaan normal dan tidak terdapat kontaminasi. Semen dengan keadaan normal pada umumnya mempunyai bau yang khas sesuai dari bau hewan tersebut. Sesuai dengan pendapat Kartasudjana (2001) yang menyebutkan bahwa semen normal umumnya memiliki bau yang khas dari hewan tersebut, apabila terdapat bau busuk menunjukkan semen bercampur dengan nanah.

Rataan derajat keasaman $(\mathrm{pH})$ semen yang diperoleh selama penelitian adalah $(7,16 \pm 0.288)$. Hafez (1993) menyatakan bahwa, semen unggas yang normal memiliki $\mathrm{pH}$ dalam kisaran 7,2 - 7,6. Toelihere (1993) menyatakan bahwa semen segar bersifat agak basa dengan rataan $\mathrm{pH}$ berkisar antara 7,0 7,6. Nilai $\mathrm{pH}$ yang tinggi selama penelitian disebabkan karena pengaruh cairan transparan atau seminal plasma dalam semen yang menyebabkan semen menjadi lebih basa.

Konsistensi yang diperoleh selama penelitian semen entog adalah encer sampai kental. Konsistensi semen berhubungan dengan konsentrasi semen yang terkandung didalamnya. Salisbury dan Van Demark (1978) menyatakan bahwa, kekentalan semen akan naik selaras dengan kandungan semennya. Konsistensi dan konsentrasi berhubungan juga dengan warna semen. Semakin tinggi kandungan semen dalam semen maka warna semen akan semakin keruh.

Rataan motilitas massa yang diperoleh selama penelitian berkisar antara
++ sampai dengan +++ (baik sampai dengan sangat baik ). Toelihere (1993) menyatakan bahwa, kualitas semen tergolong bagus jika dibandingkan motilitas massa semen mempunyai $(++)$ nilai baik dan $(+)$ kurang baik. Partodihardjo (1993) menyatakan bahwa, gerakan massa diberi skor (+++) jika terlihat gelombong besar banyak, gelap, tebal dan aktif. Skor $(++)$ diberikan jika terdapat gelombong kecil tipis, jarang, bergerak lambat dan kurang jelas. Skor $(+)$ diberikan untuk semen yang tidak menunjukkan gerakan massa bergelombong dengan jelas dan hanya nampak gerakan gerakan individu semen. Rataan persentase motilitas individu semen segar yang diperoleh selama penelitian adalah $70.00 \pm$ $5.00 \%$. Semen unggas yang normal menurut Hafez (1993) memiliki motilitas individu berkisar antara $60-80 \%$.

Rataan persentase semen hidup dalam semen segar yang diperoleh selama penelitian adalah $70.00 \pm 5.00 \%$. Hasil yang diperoleh selama penelitian menunjukkan bahwa semen mentog yang ditampung memiliki kualitas yang baik dan dapat digunakan untuk kepentingan IB.

Motilitas Semen Mentog setelah diencerkan dengan pengencer beda dan tingkat pengenceran berbeda.

Motilitas atau daya gerak semen digunakan sebagai ukuran kesanggupan semen untuk membuahi sel telur Motilitas semen merupakan salah satu yang dapat mempengaruhi fertilitas semen. Toelihere (1993) menyatakan bahwa ciri utama semen adalah motilitas atau daya gerak yang dijadikan potensi atau cara yang paling sederhana untuk penilaian semen. Motilitas bisa juga dievaluasi dengan penambahan ditambahkan bahan pengencer beda.

Rataan motilitas semen setelah penambahan dilakukan percobaan pada suhu yang berbeda pada berbagai perlakuan ditunjukkan pada Tabel suhu kamar. 
Tabel 2. Hasil rataan persentase motilitas semen mentog dengan bahan dan tingkat pengencer beda pada suhu kamar

\begin{tabular}{ccc}
\hline Macam & $\begin{array}{c}\text { Tingkat pengencer } \\
(\mathrm{X})\end{array}$ & $\begin{array}{c}\text { Motilitas } \\
(\bar{X} \pm \mathrm{SD})\end{array}$ \\
\hline I & 0 & $23.34 \pm 5.77$ \\
& 5 & $50.00 \pm 6.67$ \\
& 10 & $45.55 \pm 6.93$ \\
& 15 & $31.11 \pm 6.94$ \\
\hline II & 0 & $17.78 \pm 1.92$ \\
& 5 & $38.89 \pm 3.84$ \\
& 10 & $37.78 \pm 5.09$ \\
III & 15 & $25.55 \pm 3.85$ \\
& 0 & $15.55 \pm 6.93$ \\
& 5 & $32.22 \pm 3.85$ \\
& 10 & $37.78 \pm 8.39$ \\
& 15 & $28.89 \pm 13.46$ \\
\hline
\end{tabular}

Keterangan : I $=$ Ringer lactate $\quad$ II $=$ Otsu RL $\quad$ III $=$ Sodium chloride

Hasil menunjukkan tidak berbeda nyata $(\mathrm{P}<0.05)$, tetapi penambahan tingkat pengenceran (5 dan $10 \mathrm{X})$, di bahan pengencer I (Ringer lactate) lebih tinggi dibandingkan oshu RL dan sodium chloride. Kondisi lingkungan/kamar banyaknya $\mathrm{O} 2$ akhirnya terjadi penurunan motilitas Hal ini disebabkan karena pengencer yang digunakan mengandung sumber energy dan unsur yang berfungsi untuk mempertahankan hidup sperma, kemampuan setiap bahan pengencer untuk mempertahankan juga berbeda. Menurut Sexton dan Fewlass (1978), plasma semen merupakan medium spermatozoa untuk melakukan aktivitasnya. Jadi jika kekurangan energi. Sedangkan kandungan lactatenya masih dapat memenuhi kebutuhan ion bikarbonat yang berfungsi untuk mempertahankan keasaman larutan atau penyangga larutan serta mempertahaankan tekanan osmotik larutan sehingga $\mathrm{pH}$ tetap seimbang.

\section{KESIMPULAN}

Penggunaan 3 bahan dan tertinggi pada tingkat pengencer $5 \mathrm{X}$, dan 10 sampai $15 \mathrm{X}$ dapat mempertahankann persentase motilitas.

\section{UCAPAN TERIMA KASIH}

Tim peneliti telah menyelesaikan riset penelitian program APBU T.A 2018/2019 yang didanai oleh anggaran yayasan Uniska 2018.

\section{DAFTAR PUSTAKA}

Anonymous, 2000. Mula Duck? Metzinfo"metzer farms. Com. Internet.

D.L. Garner dan E.S.E. Hafez. 2000. Spermatozoa and Seminal Plasma. Dalam Hafez reproduction in Farm Animals 7 th Edition. Lippincot Williams \& Wilkins. Marylan USA.

Estevest, S., Sharma, R., dan Thomas, A. 2002. Effect of Swim-up Sperma washing and Subseguent Capacitation on Acrocome Status and Fungsional Membrane Integrity of Normal Spem. Departement of Urolory the ceveland Clinic Foundation Clevelani. Ohio.

Fitriani, Suyadi, Nuryadi, Sasmito. M.D., Tt. Kadar Mda Dan Integritas Membran Semen Entog Selama Penyimpanan Dingin Dengan Penambahan $\alpha$ 
Tokoferol Berbeda Dalam Pengencer . Jurnal. Fakultas Peternakan, Unibraw. Malang

Fitriani. 2009. Kajian Penambahan Alfa Tokoferol dengan Lama Penyimpanan dan Suhu Berbeda terhadap Kualitas Semen Entog. Disertasi UB.Malang.

. 2011. Tingkat Pengenceran dan dosis Semen Entog terhadap Fertilitas Telur Hasil Persilangan Entog dengan Itik Melalui Teknologi IB. Veterinaria medika.vol 4, no 3. Unair. Surabaya.
Fitriani. 2011. Pengaruh Penambahan Alpha Tocopherol terhadap Kualitas Semen Entog yang disimpan pada Suhu Dingin. Jurnal ilmu-ilmu peternakan 23 (2): 36-41 ISSN: 0852-3581. Fakultas Peternakan UB. Malang.

Partodiharjo. 1987. Ilmu Reproduksi Hewan. Mutiara Sumber Widya. Jakarta.

Toelihere, M.R, 1993. Inseminasi Buatan pada Ternak. Penerbit Angkasa bandung. Anggota IKAPI. Jawa Barat. 